\title{
IPTEKS BAGI WILAYAH (IBW) DI KECAMATAN KLOJEN KOTA MALANG
}

\author{
Mukarom $^{1)}$, Adi Sucipto ${ }^{2)}$, Indah Rakhmawati Afrida ${ }^{3)}$, \\ Djoko Andrijono ${ }^{4}$, Rusdi ${ }^{5}$, Sufiyanto ${ }^{6}$ \\ IKIP Budi Utomo Malang, Jalan Simpang Arjuno 14B Malang
}

\begin{abstract}
ABSTRAK
Development in the city of Malang is directed to bring the people of Malang City to the welfare that is distributed evenly. This condition is characterized by increasing economic growth, declining unemployment and decreasing the poor in Malang. In addition, it will also lead people to increasingly cultured conditions, with religious-tolerant values marked by an increasing understanding of traditional values, religious values, mutual respect for differences, and the absence of conflict and violence on behalf of SARA in the city of Malang. The objectives of IbW Program are: (1) To identify potential, actual condition / situation, human resources and realistic resources in Klojen Sub-district, Malang City; (2) To formulate the potential of human resources and natural resources so that it can be used as a pre-eminent commodity of the region; (3) Conducting training activities in the framework of technology transfer generated by Higher Education to the community, so that the community has the knowledge and skills in managing the potential around them. Activities were carried out using survey methods, and observations. Meanwhile, to arrange the action program is done through worshop activity with the hope of action program as needed by society. To that end, in this IbW activity the community is involved from program planning, program implementation, utilization of results and evaluation of program implementation. In this way, the action program is a program that fits the needs of the community. In addition, the implementation of community empowerment activities is carried out using field assistance method. The results of IbW program activities that have been implemented are: (1) Health Sector; Drug hazard counseling; (2) Education Sector; Improved quality of educators with Class Action Research (PTK) training; Mentoring learning for underprivileged students; (3) Economic Program; Entrepreneurship Training "Aneka Handicraft of Maize Maize", (4) Environmental Empowerment Program; Making TOGA, Greening
\end{abstract}

Keywords: IbW, Kecamatan Klojen, Kota Malang.

\section{PENDAHULUAN}

Kota Malang masih mempunyai masalah Kemiskinan, dari jumlah penduduk Kota Malang sekitar 800 ribu orang, masih ada sekitar 300 ribu warga yang kehidupannya berada dibawah garis kemiskinan. Angka kemiskinan di Kota Malang ternyata masih tinggi. Dari total jumlah penduduk 845.638 jiwa, 300 ribu jiwa diantaranya masih tercatat sebagai warga miskin. Indikator ini terungkap

dari survey yang dilakukan oleh Dinas Sosial dan Catatan Kependudukan Pemerintah Kota Malang. Berdasarkan data tersebut, mayoritas penduduk miskin di Kota Malang tersebar di semua Kecamatan di kota Malang. Kabanyakan diantara mereka hidup dengan menempati tanah-tanah milik Pemkot Malang, banyak penduduk miskin yang tinggal di kawasan bantaran sungai atau Daerah Aliran Sungai (DAS).

Masalah kependudukan di kota Kota Malang adalah masalah urbanisasi. Kota Malang bagi daerah sekitarnya mempunyai daya tarik tersendiri, sehingga mendorong masyarakat sekitarnya untuk mencari keberuntungan di Kota Malang. Tapi sumber daya manusia yang datang ke Kota Malang tersebut jarang membekali diri dengan skill yang memadai. Hal tersebut akan memberi beban tersendiri bagi kota untuk penyediaan lapangan pekerjaan.

Terkait dengan hal tersebut di Kota Malang adalah terjadi ketidakseimbangan/ masih kurang meratanya penyebaran kepadatan dan pertumbuhan penduduk. Berdasarkan data pada tahun 1997 pada satu kecamatan yaitu di Kecamatan Klojen 
terdapat Kelurahan Samaan yang tingkat kepadatan penduduknya mencapai 219 jiwa/ha, sedangkan di lain pihak pada suatu kecamatan yaitu Kecamatan Kedungkandang (kawasan Buring) kepadatan penduduknya relatif rendah yakni 35 jiwa/ha. Disini terlihat suatu ketidakseimbangan dimana terjadi beban kepadatan dan pertumbuhan yang besar di pusat kota dan bagian wilayah tertentu dan di lain pihak ada wilayah yang beban kepadatan dan pertumbuhan pemduduknya sangat lambat. Oleh karena itu pertumbuhan penduduk di kawasan pusat kota harus dikendalikan, dan sebaliknya pertumbuhan penduduk di kawasan pinggiran lebih dipacu lagi dengan memberi peluang kerja dan pusat-pusat pelayanan baru.

Perkembangan fisik Kota Malang dalam kurun 5 tahun terakhir mengalami perkembangan pesat. Masalah yang dihadapi pemerintah Kota Malang pada saat ini adalah pemukiman, dimana masyarakat kota yang mempunyai pendapatan rendah sulit mendapatkan permukiman karena faktor biaya. Hal tersebut menyebabkan kelompok tersebut mendirikan permukiman ilegal diberbagai tempat terutama kawasan dekat pusat kota.. Mengingat kurang adanya konsistensi dalam penanganan masalah penduduk, maka kawasan tersebut berkembang secara tidak teratur sehingga kawasan tersebut menjadi kumuh dan terjadi penurunan kualitas hidup.

IKIP Budi Utomo Malang kian memantapkan sinergi dengan Pemerintah Kota Malang dalam meningkatkan pembangunan dan kesejahteraan masyarakat. Sinergi tersebut dilakukan melalui program IbW (Ipteks Bagi Wilayah). Dalam program tersebut IKIP Budi Utomo Malang melaksanaan di dua kelurahan yakni di Kelurahan Rampal Celaket dan Kelurahan Samaan, Kecamatan Klojen. Kedua daerah ini ternyata banyak memiliki potensi yang belum tersentuh secara optimal," Seperti potensi yang dimiliki di Kelurahan Rampal Celaket adalah batik yang telah digeluti sebagian besar dari penduduknya.

Sebagai lembaga kependidikan IKIP Budi Utomo malang memiliki kewajiban untuk berperan serta secara aktif dalam pembangunan di bidang kelembagaan, kesehatan, pendidikan, ekonomi serta, pemberdayaan lingkungan. Peran serta tersebut bukan hanya dilakukan oleh mahasiswanya dan dosen saja, namun juga masyarakat di sekitar kampus ataupun masyarakat luas. Salah satu bentuk peran serta aktif tersebut adalah dengan program pengabdian kepada masyarakat berbasis wilayah atau IbW (Ipteks bagi Waliayah) di Kecamatan Klojen Kota Malang yang diselenggarakan oleh dosen IKIP Budi Utomo malang bermitra dengan dosen Universitas Mereka Malang.

Tujuan utama Pengabdian pada Masyarakat IbW (Iptek bagi Wilayah) adalah mendekatkan lembaga pendidikan dengan masyarakat, sehingga perguruan tinggi dapat membantu pemerintah dalam mempercepat gerak pembangunan dan mempersiapkan kader-kader pelaku pembangunan yang berkualitas. Sedangkan bagi mahasiswa yang dilibatkan dalam program $\mathrm{IbW}$ ini dapat mengembangkan kepribadian mahasiswa "Personality

Development', adapun salah satu unsur penunjang untuk mewujudkannya adalah pengembangan segi persepsi, kognisi dan sikap mahasiswa terhadap masyarakat (lingkungannya).

\section{METODE}

Kegiatan pengabdian kepada masyarakat dilakukan dengan menggunakan metode survei, dan observasi. Sedangkan untuk menyusun program aksi dilakukan melalui kegiatan worshop dengan harapan program aksi yang dihasilkan merupakan program aksi yang dibutuhkan oleh masyarakat. Oleh karena itu, dalam kegiatan IbW ini 
masyarakat dilibatkan mulai dari kegiatan perencanaan program, pelaksanaan, pemanfaatan hasil program dan evaluasi terhadap pelaksanaan program. Dengan cara seperti ini, maka diharapkan program aksi yang tersusun adalah program yang sesuai dengan kebutuhan masyarakat. Selain penyusunan program berbasis masyarakat, maka dilakukan juga implementasi kegiatan pemberdayaan masyarakat dengan menggunakan metode pendampingan di lapangan.

\section{HASIL DAN PEMBAHASAN}

Sebelum kegiatan IbW dilaksanakan, maka diadakan sosialisasi di tingkat kelurahan yakni di Kelurahan Samaan dan Kelurahan Rampal Celaket Kelurahan Rampal Celaket. Hal ini bertujuan agar masyarakat tempat melaksanakan pengabdian IbW mengetahui dan memahami serta dapat mendukung program-program yang sudah disusun oleh tim IbW. Hasil dari sosialisasi ini mendapatkan respon yang positif dari pihak kelurahan dan masyarakat di dua kelurahan tempat pelaksanaan IbW.
Kegiatan bidang ekonomi adalah Pelatihan kewirausahaan yang dilaksanakan di Balai Kelurahan Ramapal Celaket yang dihadiri Ibu-Ibu PKK dari dua kelurahan yaitu Kelurahan Rampal Celaket dan Kelurahan Samaan. Pelatihan kewirausahaan adalah pembuatan bunga dari klobot jagung, pelatihan ini sangat menarik minat IbuIbu yang hadir dalam kegiatan tersebut, mereka sangat tertarik karena beranggapan bisa memanfaatkan sesuatu yang selama ini dianggap sebagai sampah atau limbah rumah tangga ternyata bisa dibuat bunga yang indah dan bisa dibentuk menjadi macammacam kreasi. Meskipun mengalami kesulitan dalam pembuatan bunga karena belum pernah mencoba, namun dengan semangatnya peserta yang hadir, pelatihan klobot jagung ini dapat berlangsung dengan lancar. Kegiatan ini Bertujuan untuk memberikan motivasi untuk mendapatkan pengetahuan tentang manfaat limbah (daun jagung) sebagai hiasan rumah dan mengasah serta melatih keterampilan ibu rumah tangga, untuk menambah penghasilan di luar pekerjaan utama atau pekerjaan pokoknya.

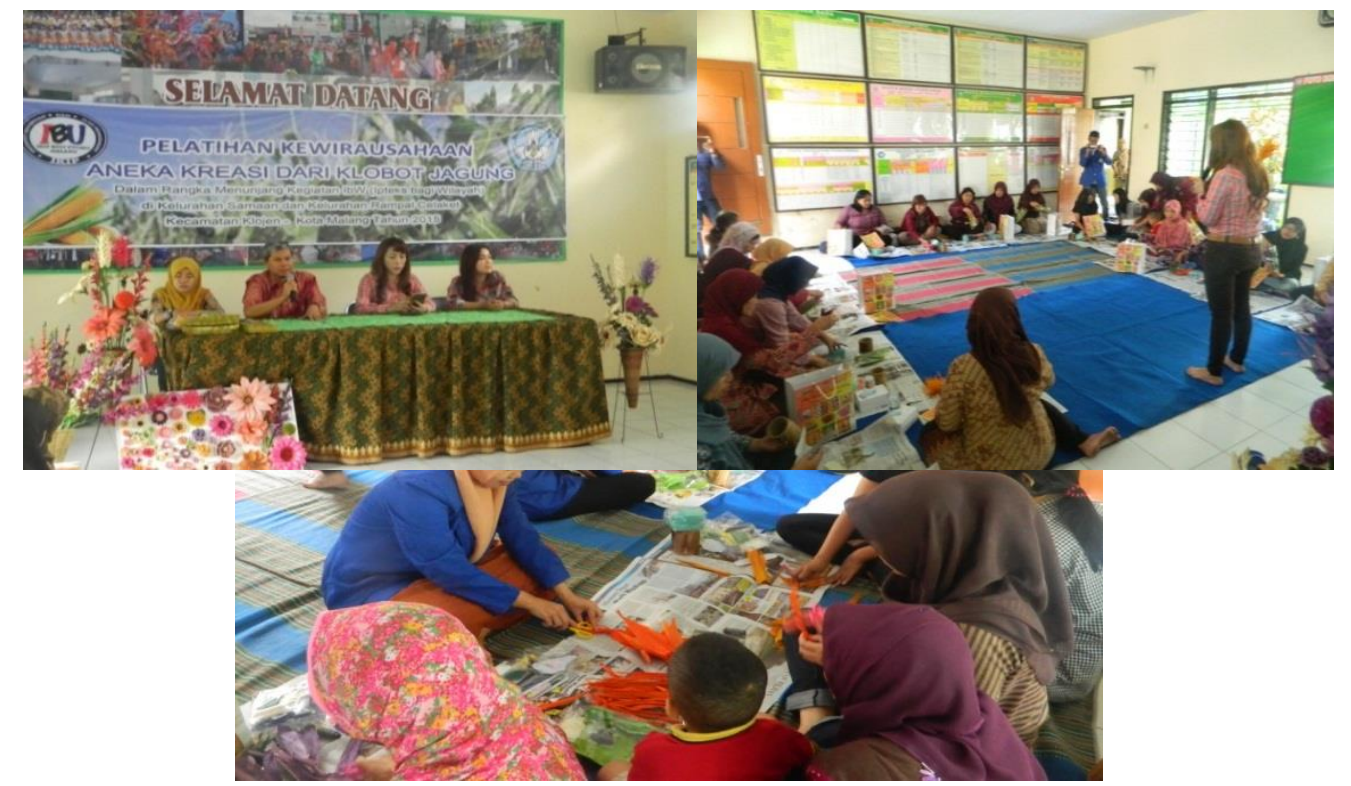

Gambar 1. Pelatihan Pembuatan Bunga dan Bros dari Klobot Jagung.

Pengabdian bidang kesehatan, adalah Penyuluhan bahaya Narkoba, denganmendatangkan narasumber dari BNN Malang dan dilaksanakan di Kantor 
Kelurahan Rampal Celaket. Pada kegiatan ini, masyarakat khususnya para remaja yang ada di wilayah Kelurahan Rampal Celaket dan Kelurahan Samaan diberitahukan tentang bahaya narkoba. Kegiatan ini sangat didukung oleh para

warga di Kelurahan Rampal Celaket dan Kelurahan Samaan Malang karena kegiatan ini merupakan kegiatan yang sangat positif yang mana dapat memberikan pengetahuan melalui penyuluhan bahaya narkoba.

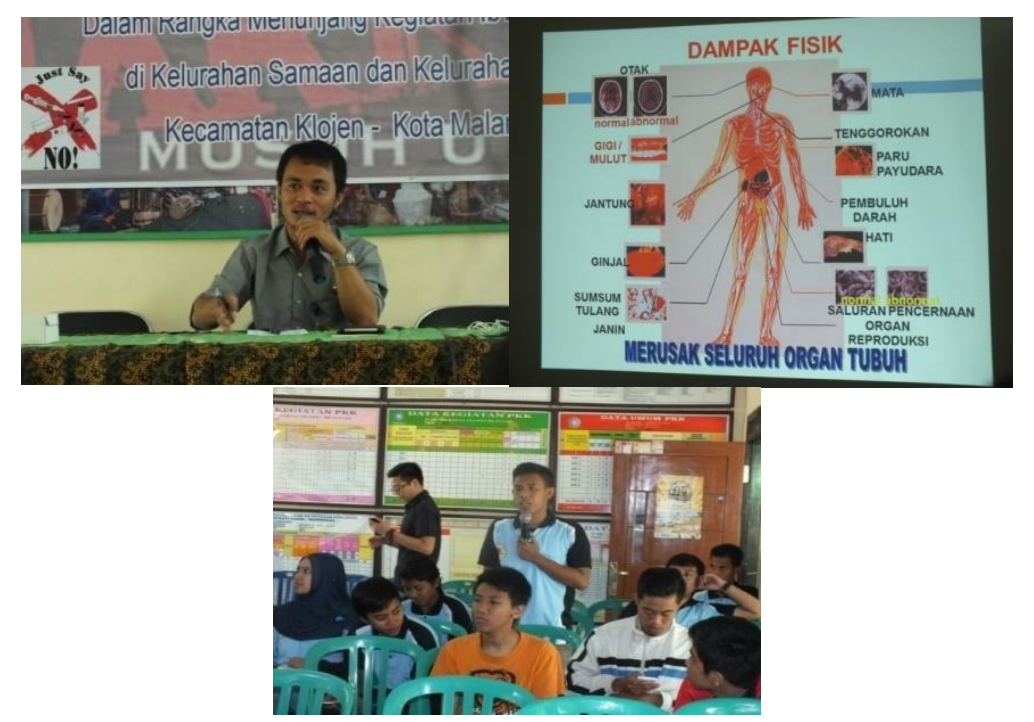

\section{Gambar 2. Kegiatan Penyuluhan "bahaya narkoba" oleh narasumber dari BBN Kota Malang}

Bidang pendidikan, adalah Pelatihan Penelitian Tindakan Kelas (PTK), Kegiatan ini diadakan pada hari Sabtu tanggal 6 Juni 2015 bertempat di SDN Rampal Celaket 2. Para pesertanya yaitu guru-guru dari SDN Rampal Celaket 1 dan 2. Jalannya acara berlangsung lancar dan kondusif. Bapak dan ibu guru terlihat antusias dan sungguh-sungguh saat mendengarkan uraian dari para pemateri. Tak hanya menyimak penjelasan dari pemateri. Namun, para guru tersebut berlatih membuat Penelitian Tindakan Kelas (PTK). Kegiatan ini diselenggarakan dengan tujuan untuk melatih para guru mampu membuat sebuah penelitian kelas untuk menangani masalah-masalah yang di hadapi para siswa dalam kelas. Sehingga ada solusi dari masalah tersebut dan membuat kegiatan belajar mengajar menjadi lancar. 


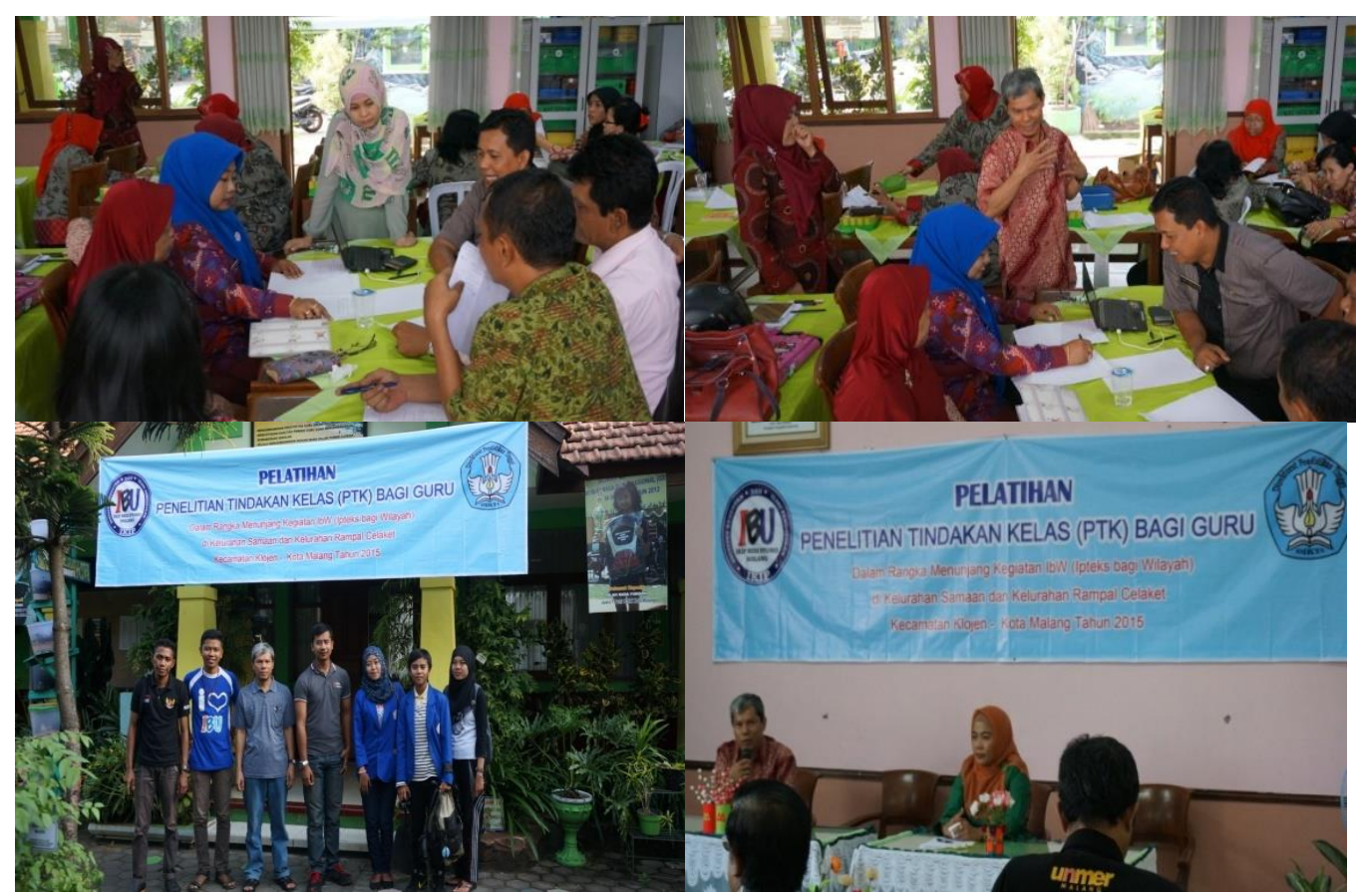

Gambar 3. Kegiatan PTK untuk Guru SDN Rampal Celaket 1 dan 2

Selain PTK kegiatan bidang penddikan adalah Bimbingan belajar, Dengan bimbingan dapat membantu para siswa dalam memecahkan masalah moral, sosial dan pendidikan. Jenis bimbingan belajar yang dilaksanakan adalah bimbingan secara berkelompok atau bersama-sama. Siswa diberikan masalah dan diberi bimbingan. Siswa dibimbing sampai memahami dan menemukan jawaban dari masalah yang dihadapi. Di sini kami bertindak sebagai fasilitator, siswa dilatih untuk menyelesaikan masalahnya sendiri, bila sewaktu-waktu diperlukan akan diarahkan untuk menemukan jawaban sendiri. Hasil yang didapatkan adalah siswa menjadi lebih semangat dan termotivasi untuk mengerjakan atau mencari jawaban dari suatu masalah.

Bimbingan merupakan suatu proses memberi bantuan pada individu agar individu itu dapat mengenal dirinya dan dapat memecahkan masalah dirinya sendiri sehingga ia dapat menjalani hidupnya dengan bahagia. Bimbingan juga merupakan suatu proses yang bertujuan agar siswa bertanggung jawab menilai kemampuannya sendiri dan menggunakan pengetahuan secara efektif dan semua potensi siswa berkembang secara optimal.

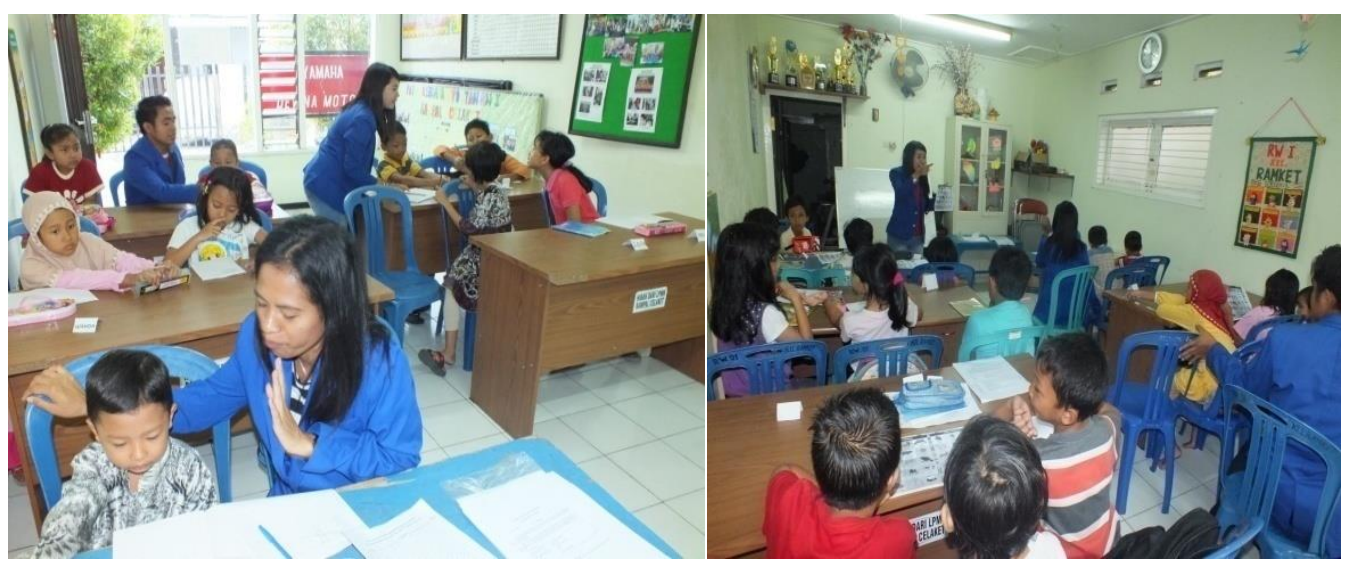

Gambar 4. Dokumentasi Bimbingan Belajar di RW 01 


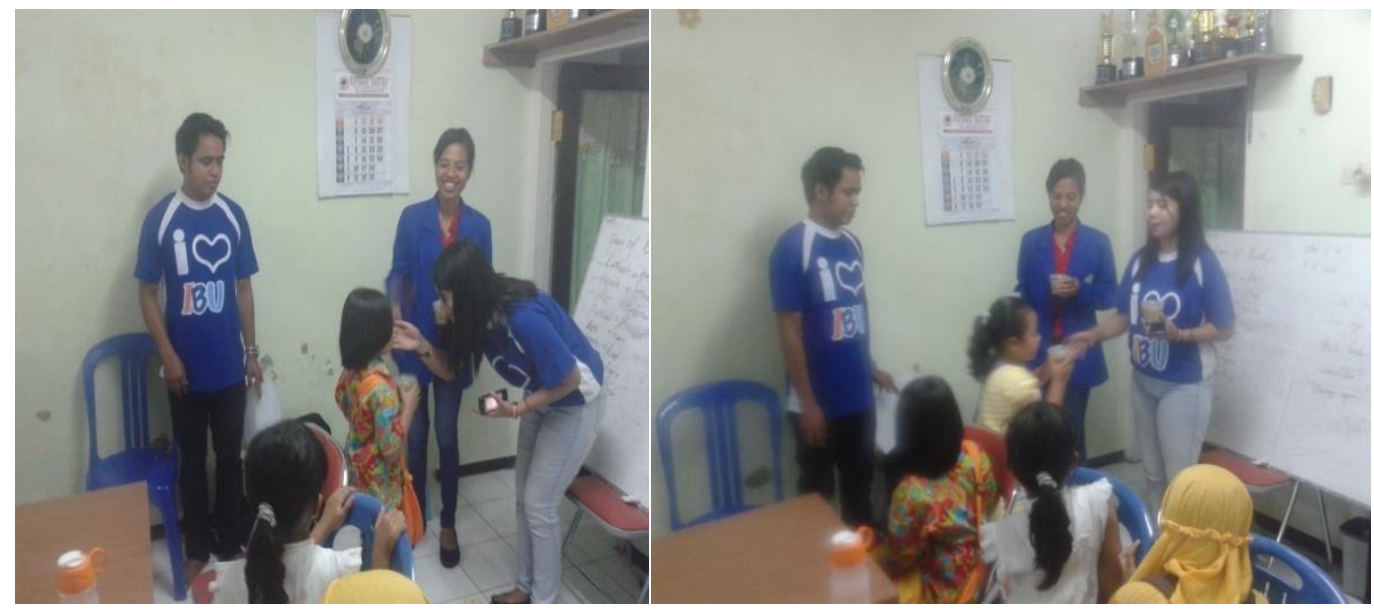

Gambar 5. Pelatihan Speaking di RW 01

Alasan adanya program bimbingan belajar ini karena kurangnya pengetahuan dan minat belajar anakanak, maka sebagai calon pendidik ini merupakan tanggung jawab yang utama untuk membantu meningkatkan kembali semangat belajar serta membantu mengenal dan memahami kemampuan untuk mengenal potensi atau bakatnya masing-masing. Selain pemberian mata pelajaran, dalam bimbingan ini juga diajarkan bagaimana sikap saling menghargai dan menghormati sesama teman, menghormati orang tua, menghormati dan menghargai siapa pun yang berbicara. Pembelajaran sikap ini dilakukan karena disadari bahwa dalam proses pembelajaran tidak hanya pengetahuan yang penting, tetapi pembelajaran sikap sejak dini.

Kegiatan bidang lingkungan, adalah Tanaman TOGA ini dilaksanakan pada tanggal 31 Mei 2015 di lokasi (Lahan kosong samping Balai RW 04 RT 4). Penanaman Toga ini merupakan hasil pesetujuan program oleh perwakilan warga dan di bantu warga dalam penanaman TOGA. Tanaman obat keluarga merupakan tanaman hasil budidaya rumahan yang berkhasiat sebagai obat. Tanaman ini membantu kebutuhan keluarga atau masyarakat akan obat-obatan. Program penanaman Tanaman Obat Keluarga ini membantu dan melengkapi Tanaman Obat Keluarga yang belum ada di RW 04 Kel.Rampal Celaket Kec. Klojen. Selain penanaman ulang serta melengkapi TOGA yang belum ada di RW 04, penanaman toga ini tentunya untuk melindungi dan meningkatkan kesejahteraan masyarakat serta melestarikan kekayaan alam melalui tanaman yang ada disekitar kita.

Manfaat yang didapat dari budidaya tanaman obat ini antara lain ; sebagai pencegahan penyakit, jika digunakan secara kontinyu serta membentuk iklim micro yang sejuk dan nyaman. Tanaman Toga ini tentunya bernilai estetika bagi keluarga dan lingkungan. Penambahan TOGA diantaranya: Jahe, Kencur, Kunyit, Lengkuas, Temu Hitam, Temu Giring, Sambiloto, Kembang Cokelat, Kumis Kucing, Jeruk Nipis, dan Temulawak. Masing-masing TOGA ini memiliki manfaat yang bermanfaat bagi masyarakat. 


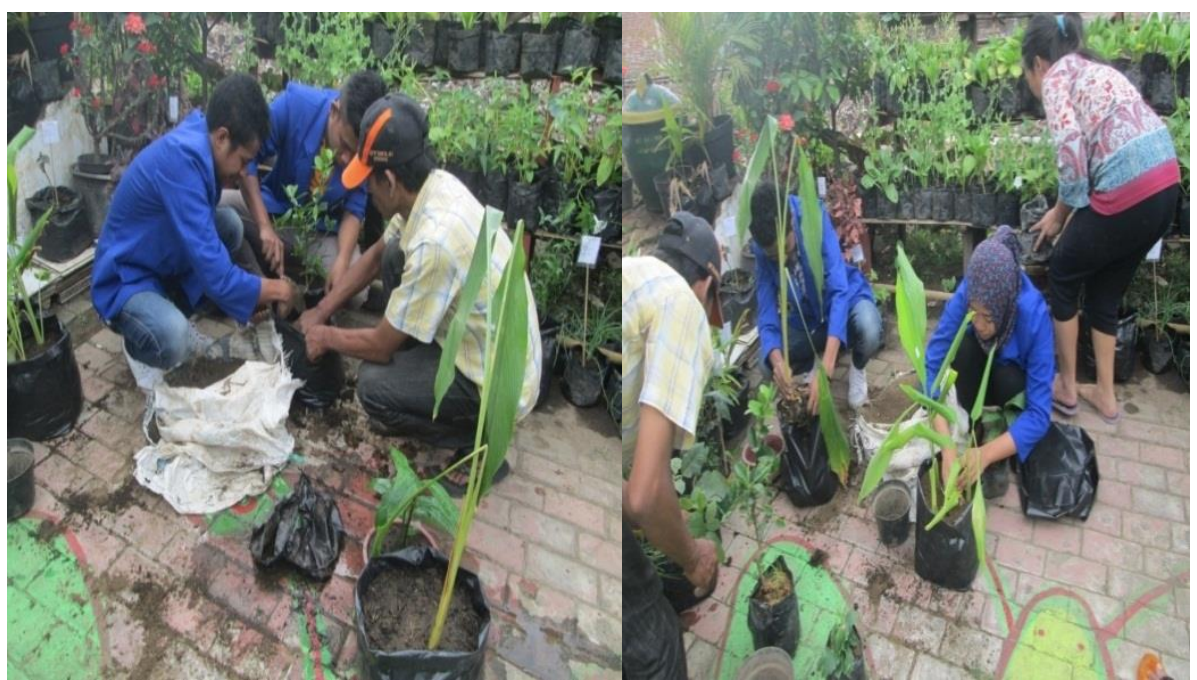

\section{Gambar 6. Penanaman toga di RW 04}

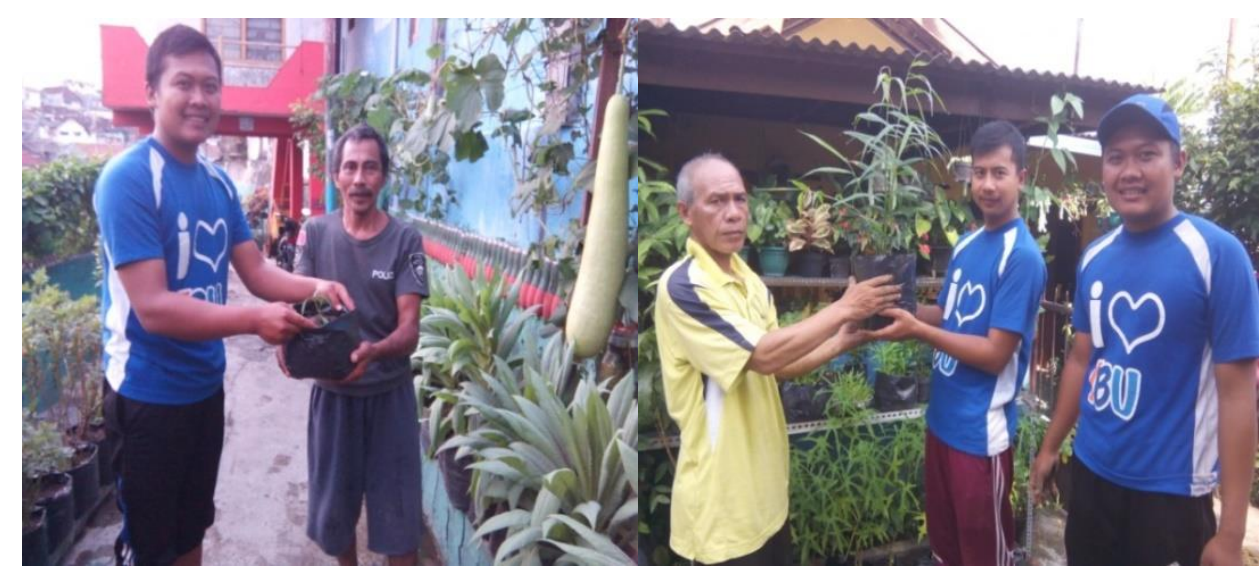

Gambar 7. Penyerahan tanaman toga kepada perwakilan warga

\section{KESIMPULAN}

Bidang pendidikan, siswa yang mengikuti program bimbingan belajar maupun pelatihan dapat memiliki kemampuan dan ketrampilan yang lebih baik untuk menunjang peningkatkan minat belajar mereka dan sebagai sarana untuk menggali potensi dari siswa itu sendiri. Pelatihan Penelitian Tindakan Kelas (PTK) Bagi Guru, telah dapat memberikan pengetahuan dan keterampilan bagi guru dalam membuat karya ilmiah dalam bentuk PTK. Bidang ekonomi, dengan Pelatihan Kewirausahaan Aneka Kreasi dari Klobot Jagung, telah dapat memberikan keterampilan berwirausaha kepada masyarakat di Kelurahan samaan dan Kelurahan Rampal Celaket. Bidang lingkungan, telah terbentuk beberapa Tanaman Obat Keluarga (TOGA) seperti di RW.05, RW.01 Kelurahan Samaan dan di RW.01, RW.04 serta RW.06. Kelurahan Rampal Celaket. Bidang kesehatan, Penyuluhan bahaya narkoba telah dapat memberikan pengetahuan dan pemahaman kepada anak-anak remaja di Kelurahan Samaan dan Kelurahan Rampal Celaket tentang penyalahgunaan narkoba yang dapat mengancam masa depan mereka. 


\section{DAFTAR RUJUKAN}

Achmad Syaiful Afandi, Kota Malang Akan Miliki Sentra Batik, dalam Seni Budaya dan Pariwisata, Jumat, 8 November 2013

Achmad Syaiful Afandi, Kurangi Angka Kemiskinan Melalui Posdaya, dalam Berita, Sosial dan Kesra, Sabtu, 1 Maret 2014.

Cahyo Nugroho, Pecinta Mainan Tradisonal Rampal Celaket Show di Kampung Cempluk, dalam Seni Budaya dan Pariwisata, Sabtu, 28 September 2013

(http://mediacenter.malangkota.go.id/201 4/03/optimis-kurangi-angkakemiskinan-melaluiposdaya/\#ixzz2wl4fBDE1, diakses, 22 Maret 2014)

(http://mediacenter.malangkota.go.id/201 3/11/kota-malang-akan-milikisentra-batik/\#ixzz2wktj0g1s, diakses 23 Maret 2014)

(http://mediacenter.malangkota.go.id/201 3/09/pecinta-mainan-tradisonalrampal-celaket-show-di-kampungcempluk/\#ixzz2wkw1doiO, diakses 24 Maret 2014)

http://www.malangkota.go.id/halaman/16 060714\#ixzz2wkuWsX5g, diakses 23 Maret 2014) http://www.malangkota.go.id/halaman/16 06073\#ixzz2wZ70xBpe, diakses 24 Maret 2014)

Kota Malang Dalam Angka 2013.MalangPos, Angka Kemiskinan Kota Malang Masih Tinggi, Senin, 24 Februari 2014

Panduan Pelksanaan Penelitian dan Pengabdian Kepada Masyarakat di Perguruan Tinggi Edisi XI Tahun 2017

Pedoman Pengabdian Kepada Masyarakat Berbasis Potensi (PMBP) IKIP Budi Utomo Malang Tahun 2014.

RPJMD Kota Malang.

Saefullah, Entaskan Kemiskinan, Pemkot Mala ng Gandeng $32 \quad$ PT 05/03/2014, Malang, DUTA ONLINE.

Yatimul Ainun, Problem Kemiskinan, 15 Balita di Malang Alami Gizi Buruk, Kamis, 25 April 2013, Malang, KOMPAS.com 